\title{
Branding Islamic Heritage to Promote Tourism in Bangladesh
}

\author{
*Md. Sohel Rana ${ }^{1}$ \\ ${ }^{1}$ Lecturer, Department of Business Administration, Pundra University of Science \& Technology, \\ Bogra, Bangladesh. \\ Corresponding Author: Md. Sohel Rana ${ }^{l}$
}

\begin{abstract}
As Bangladesh is one of the largest Muslim countries in the world it captures many Islamic heritage sites those are renowned all over the world. It includes unique designed mosques, tombs, shrines in almost all the districts of Bangladesh those are very attractive in nature and it can create appeal to the Muslim as well as non-Muslim tourists from home and abroad. This paper explores the concept of Islamic tourism with its various terminologies. The paper also describes briefly the major attractions of Islamic heritage in Bangladesh in front of the national and international tourists.
\end{abstract}

Key Terms:Tourism, Islamic heritage, Bangladesh.

Date of Submission: 03-07-2017

Date of acceptance: $15-07-2017$

\section{Introduction}

Nowadays tourism plays a great role for economic development of any country. In Muslim world this idea converted to Islamic tourism that contributes to its economy year by year. As Bangladesh is one of the largest Muslim countries of the world it has many Islamic heritage sites to attract tourists from home and abroad.At this moment Bangladesh needs to present its various Islamic heritage sites towards the Muslim tourists as well as non-Muslim tourists.

- To clarify the concept of Islamic tourism.

\section{Objective Of The Study}

- To introduce with the various terminology of Islamic tourism.

- To describe briefly the major attractions of Islamic heritage in Bangladesh.

- To provide some recommendations to increase the attractiveness of Islamic heritage in Bangladesh.

\section{Islamic Tourism}

Say: "Travel through the earth and see how Allah did originate creation; so will Allah produce a later creation: for Allah has power over all things" (Surat Al-Ankabout, 20).

Say: "Travel through the earth and see what was the end of those who rejected Truth" (Surat AlAn'am, 11)."Do they not travel through the earth, and see what was the end of those before them?" (Surat Mohammed, 10). Above these are some of the verses from the holy Quran where it motivates the mankind to travel and to see the creations of the creator Allah (swt). So, Islam and tourism are very closely related with each other.Due to the adverb "Islamic", Islamic Tourism is usually perceived as a type of tourism involving Islam and/or Muslim Travellers. Thus, Islamic Tourism typically describes Muslim tourists travelling to destinations where Islam is the official or dominant faith, often for reasons connected to religion. (Organization of the Islamic Conference, 2008)

As World Tourism Organization (WTO) defines_ Tourism comprises the activities of persons travelling to and staying in places outside their usual environment for not more than one consecutive year for leisure, business and other purposes not related to the exercise of an activity remunerated from within the place visited.So, in this perspective, Islamic tourism can be defined as the activities of Muslims travelling to and staying in places outside their usual environment for not more than one consecutive year for participation in those activities that originate from Islamic motivations which are not related to the exercise of an activity remunerated from within the place visited.

Islamic Tourism is defined as any activity, event, experience or indulgence, undertaken in a state of travel that is Islamically compliant, with the purpose to interface within an Islamic framework, with one or all of the following; history, arts, culture, heritage, way of life, economy, health, education and any other human interests. (ITC, Malaysia)According to Duman (2011) "Islamic tourism" can be defined as "the activities of Muslims traveling to and staying in places outside their usual environment for not more than one consecutive year for participation of those activities that originate from Islamic motivations which are not related to the 
exercise of an activity remunerated from within the place visited".Islamic tourism is defined as "Any activity, event and experience undertaken in a state of travel that is in accordance to Islam"- Islamic Tourism Centre, 2011.All product development and marketing efforts designed for and directed at Muslims. Motivations are not always or entirely religious. Participants could be pursuing similar leisure experiences to non-Muslims, albeit within parameters set by Islam, and destinations are not necessarily locations where Shariah or full Islamic law is enacted. (Henderson 2010)So Islamic Tourism indicates the travelling to any destinations/Muslim heritagefor religious purposeswhile following Islamicprinciplesin order to understandIslam and Islamic culture.

\section{Terms Related With Islamic Tourism}

- Halal Tourism: Islamic tourism is also known as halal tourism.Halal Travel is now an established concept in the tourism industry, providing travel and tourism services in accordance with Muslim beliefs and practices.

- Halal Food: Halal is Arabic for permissible. Halal food is that which adheres to Islamic law, as defined in the Quran and Sunnah.

- Hajj \&Umrahtravel: Muslims travelling for performing Hajj or Umrah. Hajj \&Umrah travel is a subset of Islamic travel. It should be noted that Hajj \&Umrah travel make up most of Islamic travel.

- Halal Hotel: A Hotel which has taken into account all the key needs of Muslim travellers including having only Halal food \& beverages, prayer information and facilities, prayer/qiblah directions, the ability to cater during non-standard hours in the month of Fasting, water-friendly washrooms etc.

- OIC Countries: The Organization of Islamic Cooperation. It brings together 57 states/countries. $82 \%$ of the total population of these countries is Muslim and this constitutes approximately $80 \%$ of the global Muslim population. These countries are sometimes also referred as Islamic countries or Muslim countries.

\section{Major Islamic Heritages In Bangladesh}

There are a large number of Islamic heritage sites in Bangladesh and visitors can find unique designed mosques, tombs, shrines in almost all the districts of Bangladesh. The major attractions of Islamic heritage sites of Bangladesh are briefly described in the following:Star Mosque, Dhaka: Star Mosque, locally known as Tara Masjid, is a mosque located in Dhaka. It is situated at the Armanitola area of the old part of the city. The mosque has ornate designs and is decorated with motifs of blue stars. The mosque is decorated with imported Japanese and English china clay tiles and utilized both methods of the Chinitikri application.

BaitulMukarram Mosque, Dhaka: BaitulMukarram Mosque is situated at PuranaPaltan east of Bangladesh Secretariat and north of Dhaka Stadium. This is the largest mosque in the city, three storied and built after the pattern of the Kaba Sharif. It has very beautiful and costly decorations in the interior and there is a long lawn, garden and rows of fountains to the south and east. Shat-Gambuj Mosque, Bagerhat: In mid-15th century, a Muslim colony was founded in the inhospitable mangrove forest of the Sundarbans near the sea coast in the Bagerhat district by an obscure saint, named Ulugh Khan Jahan. He was the earliest torch bearer of Islam in the South who laid the nucleus of an affluent city during the reign of Sultan Nasiruddin Mahmud Shah (144259), then known as 'Khalifalabad' (present Bagerhat).

Museum in front of the ShaitGumbaz Mosque:A small museum has been established by the Directorate of Archaeology of Bangladesh, in collaboration with UNESCO, in front of the ShaitGumbaz Mosque, where antiquaries collected from the area of the historical site are displayed providing knowledge on the history of Bagerhat. It has three exhibit galleries of antiquaries related to the "Historic Mosque City of Bagerhat", which include inscriptions, potteries, terracotta plaques and ornamental bricks. Pictures of important historic buildings of Bangladesh are also part of the exhibits here.Nine dome Mosque: The Nine Dome Mosque is located to the west of the takurdighi tank and built in the 15th century, it is close to Khan Jahan Ali's Tomb. Its western wall conventionally faces west towards Mecca, where the mihrab is inset on the western wall; terra cotta floral scrolls and flower motifs are the decorations seen around the mihrab. Circular towers are provided in the four corners. The walls of the mosque support a large central dome which has eight smaller domes around it. This structure was also affected by sulphates. It has been since substantially restored. Close to this mosque are the ZindaPir Mosque and mazar (tomb), which are in ruins.

Singara Mosque: The Singara Mosque is across the road from the SaithGumbaz Mosque on its southeastern side. It has a single dome which is heavily built and a wide dome. In the typical style of the Khan Jahan Ali, the dome is supported on thick walls and topped with a cambered cornice. The BigiBegni Mosque and the ChunaKhola Mosque are also of single dome type but much larger in size compared to the Singara Mosque. Last reported, the mosque was in a state of decay and renovation works were envisaged.

Ronvijoypur Mosque: The Ronvijoypur Mosque has the largest dome in Bangladesh. It is of 11 metres (36 ft) width supported by arches and pendentives. The corners have tapering circular turrets while the external cornice has a slight curve. The mosque's interior is plain. However the main mihrabs have decorations of floral patterns. It is located on the opposite side of the Khan Jehan Mausoleum, on the Khulna Bagerhat road. It is 
built according to Khan Jehan style of architecture. It has been renovated many times in the past during the 1960s and 70s. However, it needs further repair work to prevent dampness inside the tomb, and also to the brickwork on the exterior surfaces.

The ChunaKhola Mosque: The ChunaKhola Mosque, built in the 15th century, is located in the midst of rice fields in the village of ChunaKhola (named after the limestone extraction that was in vogue here in the past). It is distinctly different from the Khan Jehan style mosque in its exterior decorations, particularly the east façade, which depicts four rectangular panels bordered by foliated scrolls with merlons having plant motifs. It has four turrets with curved cornices. The brick walls, in particular, were damaged due to sulphate effect. It was renovated in the 1980s according to guidelines set by UNESCO.

Six-Domed Mosque: The Six-Domed Mosque (also called the Rezakodha Masjid), built in the 15th century near thakurdighi pond, had six domes supported by stone columns. Protected under the Antiquities Act, the main mihrab displayed a chain and bell design. However, since it was all in ruins, a new building had been built, which has since been removed and the old ruins retained.ChotaSona Mosque, Rajshahi: It is a remarkably fine architectural specimen of the Sultante Period. It was built by Wali Muhammad son of Ali during the reign of Sultan Hossain Shah (1493-1519). It has fifteen gilded domes including three chauchala domes in the middle row. Chief attractions of the Mosque are its intricate stone carvings and decoration.

Mosque of Baba Adam, Dhaka:Of a slightly later date the elegant 6-domed mosque of Baba Adam in Rampal near Dhaka was erected by one Malik Kafur during the reign of the last IllyasShahi Sultan, JalauddinFateh Shah in 1483 A.D. It displays the same characteristic features of the period such as the faceted octagonal turrets at 4 corners, the curved cornice, the facade and 3 mihrabs relieved richly with beautiful terracotta floral and hanging patterns.Gorer Mosque, Jhinaidah:It is a single domed square mosque with its entrances on the east. It is entirely built of bricks and datable to the 15th century AD.

Bagha Mosque, Rajshahi:Built in 1523 A.D. by Sultan Nusrat Shah, son of Hussain Shah, it is a richly decorated monument originally roofed over with 10 domes which collapsed long ago but recently rebuilt carefully to their original form. The superb terracotta decoration on the central mihrab represents floral frame work and jali rosettes. The whole outer surface of the mosque is beautifully embellished with fine terracotta art motifs.BinatBibi Mosque: This pre-Mughal building is the oldest mosque built in Dhaka. According to an inscription, BakhtBinat, daughter of Marhamat, built it 15th Century dated in 1454 during the rule of Sultan Mahmud Shah I.Atiya Mosque: Constructed in 1609 A.D. by Sayyed Khan Pani, son of Bayazid Khan Pani, the mosque $(21 \mathrm{~m} \times 12.19 \mathrm{~m})$ consists of a single domed square prayer chamber fronted by a verandah covered over by 3 domes. Its cornice is deeply curved and wall surface is relieved with terracotta ornamental panels showing a blending of Mughal and pre-Mughal architectural traits.Shahi Mosque: This elegant three- domed mosque is located to the west of the fort built by prince Azam in 1678 A.D. The architectural decorations, interior and exterior follow the usual Shaista Khan style. One of the most interesting features of this mosque is its fresco design underneath the domes. Besides, the domes are ribbed externally.

Musa Khan Mosque: Musa Khan (reigned: 1599-1610) son of Isa Khan was the leader of BaraBhuiyans (twelve landlords of medieval Bengal) of the Bhati region. Musa Khan Mosque is located on the western side of the Shahidullah Hall of Dhaka University, and is less than half a $\mathrm{km}$ to the south of the KhwajaShahbaz's Mosque. A high vaulted plinth with a three-domed mosque above and the grave of Musa Khan to its northeast comprise the mosque complex of Musa Khan.

Goaldi Mosque: Goaldi Mosque is an elegant little pre-Mughal mosque Built in 1519 by MullaHizabar Akbar Khan, during the reign of Alauddin Husain Shah at a place called Goaldi, half a mile northeast of Panam village in SonargaonUpazila of Narayanganj District. Single-domed Goaldi Mosque is a good example of the 'enclosed square type' mosque of Sultanate period.Bara Katra: Bara Katra an architectural relic of Dhaka city. It is situated to the south of Chawk Bazar close to the bank of the river Buriganga.The Bara Katra contains two inscriptions in Persian; one records that it was built in 1053 AH (1643-44 AD) and the other contains the date $1055 \mathrm{AH}$ (1645-46 AD) and confirms that SHAH SHUJA gave the building to Mir AbulQasim to be used as a Katra on the condition that the officials in charge of the endowments (waqf) should not take any rent from any deserving person alighting therein.

ChhotaKatra: ChhotaKatra, Dhaka is situated about around 183 meter east of the BaraKatra at Hakim HabiburRahman lane on the bank of the river Buriganga in Mughal (old) Dhaka.The ChhotaKatra is believed to have been built by Shaista Khan in about 1664 AD. It is also said that the Katra was constructed to accommodate some officials and also a part of Shaista Khan's expanding family. Mausoleum of GhiyasuddinAzam Shah: GhiyasuddinAzam Shah (1390-1411 CE) was the third Sultan of the first IlliyasShahi dynasty of Bengal and one of the more widely known of medieval Sultans of Bengal. Tomb of GhiyasuddinAzam Shah is situated in Narayanganj District of Bangladesh.

The Shrine of Hazrat Shah Jalal, Sylhet: Among the several places of historical interest in Sylhet town, the shrine of Saint Hazrat Shah Jalal is famous. Even today, more than six hundred years after the death of the saint, the shrine is visited by innumerable devotees of every caste and creed who make the journey from far 
away places. Hazrat Shah Jalal is credited with the help extended to the Muslim army which conquered Sylhet in 1303 A.D.

Shrine of Khan Jahan Ali, Bagerhat:Khan Jahan Ali, also known as Ulugh Khan and Khan-i-Azam, was a Muslim Sufi Saint and local ruler at Bagerhat in Bangladesh. The official title Khan-i-Azam signifies that he was an officer of the Bengal Sultan Nasiruddin Mahmud Shah I (1437-1459). The word Ulugh before his name speaks of his Turkish origin. It is believed that he built the great ShaitGumbuj Mosque.

Shrine of Sultan BayazidBostami, Chittagong: Situated on a hillock in Nasirabad, about $6 \mathrm{~km}$. to the north-west of Chittagong town, this shrine attracts a large number of visitors and pilgrims. At its base there is a large tank with several hundred tortoises. Tradition has it that these animals are the descendants of the evil spirits (genii) who were cast into this shape because they incurred the wrath of the great saint who visited the place about 1,100 years ago.

Shrine of Shah Amanat, Chittagong: The shrine of Shah Amanat is another place of religious attraction. Located in the heart of Chittagong town, the shrine is visited by hundreds of people everyday who pay homage to the memory of the saint who lived in the 19th century.Shrine of Hazrat Shah Paran, Sylhet:Hazrat Shah Paran was a Sufi saint of the Jalalia section of the Suhrawardiyya order. He was the nephew of Shah Jalal and was born in Hadramaut, Yemen, and accompanied his uncle, Shah Jalal, with whom he arrived in India in 1303 AD. He took part in the expedition of Sylhet which was led by Shah Jalal. After the conquest of Sylhet he established a khanqah at Khadim Nagar in DakshingarhPargana, about $7 \mathrm{~km}$ away from Sylhet town, where he started Sufi spiritual practices and activities. He played a significant role in propagating Islam and establishing Muslim rule in the Sylhet region. In every year "Urs" including Doa, miladmahfil, shirni and prayer sessions are held during this religious programme at the shrine of Hazrat Shah Paran in Sylhet.

\section{Recommendations}

$\checkmark$ Buildingproper infrastructural facilities encouraging to Islamic tourism that includes Islamic resorts and hotels, alcohol-free accommodations in which gender-segregation and the dress code will be strictly respected and controlled.

$\checkmark$ Arranging Islamic tourism events where gender segregated sports and wellness facilities are available.The Ministry of Civil Aviation and Tourism of the government of the People's Republic of Bangladesh, Bangladesh Tourism Board and Bangladesh Parjatan Corporation can arrange such kind of events.

$\checkmark$ Involving of media in Islamic tourism efforts to promote Islamic tourism through establishing satellite channel, newspaper and other media.

$\checkmark \quad$ Making proper marketing strategyto attract more Muslim and non-Muslim tourists towards our Islamic heritage sites. Bangladesh must have to develop positive image as a Muslim country to focus the Islamic tourism.

$\checkmark$ Maintaining proper co-ordination among Muslim countries of the world to develop Islamic tourism. Bangladesh can arrange joint tourism packages with other Muslim countries to attract huge tourists from all over the world.

$\checkmark$ Taking proper steps to create awareness about Islamic tourism among our local people.The concerned authority can arrange different programs and seminars to circulate the spirit of Islamic tourism around thecountry.

$\checkmark \quad$ Building and maintaining a good relationship and linkage withOIC countries to promote Islamic heritage sites of our country as it is the highest platform for the Muslimcountries.

$\checkmark \quad$ Taking the advantage of public private partnership to implement Islamic tourism more successfully.

\section{Conclusion}

Since Islamic tourism is anestablished concept, in the long run, it brings sustainable tourism development for the country. To expand Islamic tourism, the Islamic heritage sitesshould be preserved for domestic and foreign tourists. Such places should be kept free from any illegal encroachment, chaos and pollution. It is hoped that Bangladesh will quickly move forward to exploit the potentials of Islamic tourism in favor of its national development.

\section{References}

[1] Translation of the Holy Al-Quran.

[2] Islamic Tourism Centre, Malaysia, website: www.itc.gov.my

[3] http://tourismboard.gov.bd

[4] Henderson, J. C. (2010). Chapter 6: Islam and tourism. In Bridging Tourism Theory and Practice. Scott, N. and Jafari, J. (eds), 7589. Emerald Group Publishingn, J. C. (2010).

[5] Din, K. (1989). Islam and Tourism: Patterns, Issues and Options. Annals of Tourism Research 16: 542-563.

[6] Islam, S. M. N. (2009), "Tourism Marketing in developing Countries- A study ofBangladesh" Understanding Places - An interdisciplinary PhD research conference, Westminster Business School, University of Westminster, London, UK, July 6th 2009.

[7] Hassan, A. R. (2008). Islamic tourism: A matter of faith. Islamic Tourism, 33, 2. 
[8] Medlik, S. (2003). Dictionary of Travel, Tourism and Hospitality. 3rd ed. MA, USA: Butterworth - Heinemann.

[9] https://en.wikipedia.org

[10] Kashedul W Tuhin\&Tofael H Majumder,) An Appraisal of Tourism Industry Development in Bangladesh, European Journal of Business and Management, Vol 3, No.3,page 287-296.

[11] http://visitbangladesh.gov.bd/

[12] http://www.parjatan.portal.gov.bd/

[13] Uddin, Mohammed Asraf\& Ahmed, Shaheen (2005):’Tourism in Bangladesh: Present status, Problems and Prospects", Journal of Business Studies, Southeast University, Vol-1, No-2, July (P.143-154).

[14] Mollah, Moniruzzaman\&Hossain, Mohammed Mosaraf (2009):" Tourism Industry in Bangladesh: Problems and prospects", Journal of The People's University of Bangladesh, Vol-4, No-1, July (P.146-162).

[15] Rahman, Md. Lutfur; Hossain, S. M. Nawshad; Miti, SaniaSifat; Kalam, A. K. M. Abdul (2010). "An Overview of Present Status and Future Prospects of the Tourism Sector in Bangladesh" Journal of Bangladesh Institute of Planners, Vol. 3, December 2010, pp. 65-75, - $\quad$ Bangladesh Institute of Planners, ISSN 2075-9363. Retrieved from http://www.bip.org.bd/SharingFiles/journal_book/20130722134114.pdf

\footnotetext{
Md. Sohel Rana. "Branding Islamic Heritage to Promote Tourism in Bangladesh." IOSR Journal of Business and Management (IOSR-JBM) 19.7 (2017): 36-40. 